Oral presentation

Open Access

\title{
Molecular steps in sGC activation
}

Elizabeth M Boon ${ }^{1}$, Stephen PL Cary ${ }^{1}$, Shirley H Huang2,

Jonathan A Winger ${ }^{1}$, Emily R Derbyshire ${ }^{2}$, Mark S Price ${ }^{2}$, William K Erbil ${ }^{1}$ and Michael A Marletta*1,2,3

Address: ${ }^{1}$ Department of Chemistry, University of California, Berkeley, Berkeley, CA 94720, USA, ${ }^{2}$ Department of Molecular and Cell Biology, University of California, Berkeley, Berkeley, CA 94720, USA and ${ }^{3}$ Lawrence Berkeley National Laboratory, Berkeley, CA 94720, USA

Email: Michael A Marletta* - marletta@berkeley.edu

* Corresponding author

from $3^{\text {rd }}$ International Conference on cGMP Generators, Effectors and Therapeutic Implications

Dresden, Germany. 15-17 June 2007

Published: 25 July 2007

BMC Pharmacology 2007, 7(SuppI I):S27 doi:10.1186/147I-2210-7-SI-S27

This abstract is available from: http://www.biomedcentral.com/|47|-22I0/7/SI/S27

(C) 2007 Boon et al; licensee BioMed Central Ltd.

In higher animals, soluble guanylate cyclase (sGC) functions as a selective sensor for NO. sGC belongs to a larger family of proteins termed the H-NOX family ( oxide/OXygen binding proteins) that includes prokaryotic counterparts from aerobic and anaerobic organisms [15]. A molecular basis for the ligand discrimination against $\mathrm{O}_{2}$ in NO-regulated sGCs has been proposed $[4,5]$ and further results support the general aspects of the hypothesis that involve a H-bonding residue in those H-NOXs that bind $\mathrm{O}_{2}$ (Fig. 1).

This hypothesis has been tested by genome searching and biochemical experiments and indeed, $\mathrm{O}_{2}$-regulated cyclases have been found in C. elegans [6] and other organisms.
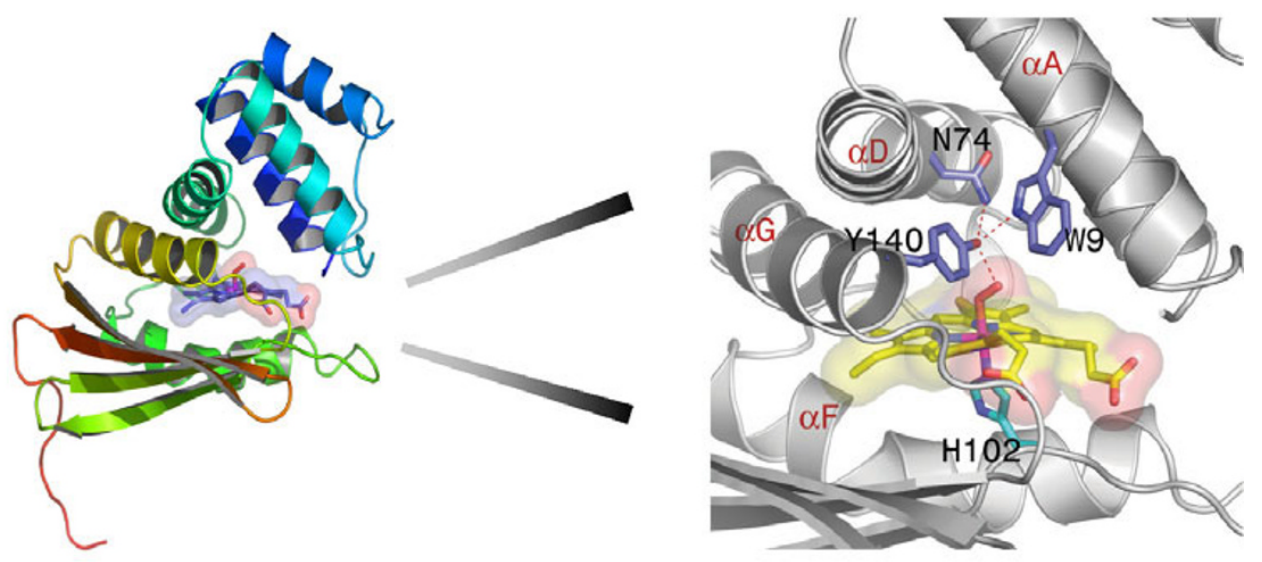

Figure I

Oxygen binding site in the T. tengcongensis H-NOX domain. Shown on the right are the key residues involved in coordinating the bound $\mathrm{O}_{2}$ including $\mathrm{Y} / 40$ [4]. 

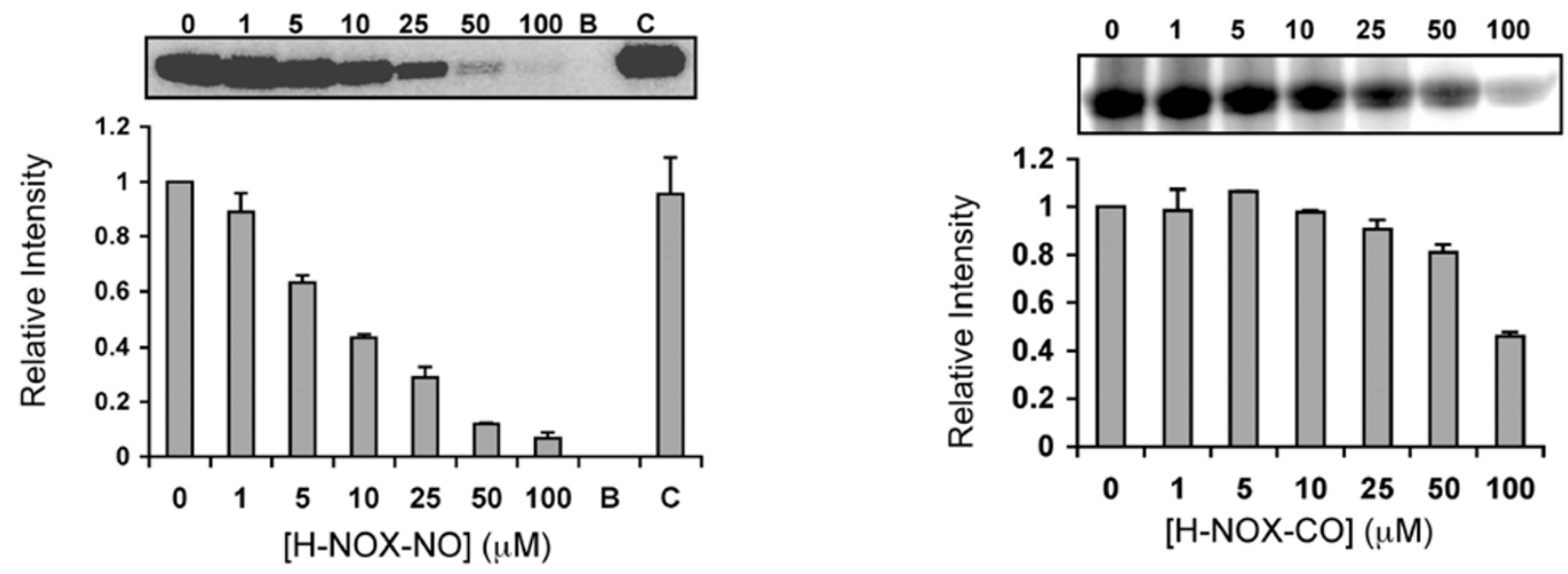

Figure 2

Effect of the SO2I44 H-NOX on the kinase activity of SO2I45. Kinase assays with SO H-NOX analyzed by SDS-PAGE/autoradiography. Top: Autoradiograph. $\mathrm{B}$ is a blank lane; $\mathrm{C}$ is a control with unligated $\mathrm{H}-\mathrm{NOX}-\mathrm{Fe}^{2+}$. Bottom: Plot of relative signal intensity. The $\mathrm{H}-\mathrm{NOX} \mathrm{Fe}^{2+}-\mathrm{CO}$ (right panel) complex has little effect on kinase activity. Top: Autoradiograph. Bottom: Plot of relative signal intensity.

Most recent results suggest that some bacterial H-NOXs, such as that from Shewanella oneidensis, are serving as NO sensors. In $S$. oneidensis the NO-bound complex of the $\mathrm{H}$ NOX selectively controls the activity of a cognate histidine kinase. The unligated H-NOX and CO complex have no effect on kinase activity (Fig. 2).

In addition, further structural studies have delineated the conformational changes that take place upon activation of an NO sensor prokaryotic H-NOX domain. Relevance of these conformational changes to sGC is being investigated. A recnt report bearing on this has appeared [7].

NO binding to the heme remains as a key molecular activation step; however, it has become clear that activation and deactivation are regulated in a complex manner [810]. Evidence suggests regulation by an additional NO binding site and allosteric regulation by ATP and GTP.

\section{Acknowledgements}

We gratefully acknowledge financial support from the NIH (GM07067I), and the Aldo DeBenedictis Fund.

\section{References}

I. lyer LM, Anantharaman V, Aravind L: Ancient conserved domains shared by animal soluble guanylyl cyclases and bacterial signaling proteins. BMC Genomics 2003, 4:5.

2. Karow DS, Pan D, Tran R, Pellicena P, Presley A, Mathies RA, Marletta MA: Spectroscopic characterization of the soluble guanylate cyclase-like heme domains from Vibrio cholerae and Thermoanaerobacter tengcongensis. Biochemistry 2004, 43:10203-102II.

3. Nioche P, Berka V, Vipond J, Minton N, Tsai AL, Raman CS: Femtomolar sensitivity of a NO sensor from Clostridium botulinum. Science 2004, 306:1550-1553.

4. Pellicena P, Karow DS, Boon EM, Marletta MA, Kuriyan J: Crystal structure of an oxygen-binding heme domain related to sol- uble guanylate cyclases. Proc Natl Acad Sci 2004, 10I:I2854-I2859.

5. Boon EM, Huang SH, Marletta MA: A molecular basis for NO selectivity in soluble guanylate cyclase. Nat Chem Biol 2005, I:53-59.

6. Gray JM, Karow DS, Lu H, Chang AJ, Chang JS, Ellis RE, Marletta MA, Bargmann $\mathrm{Cl}$ : Oxygen sensation and social feeding mediated by a C. elegans guanylate cyclase homologue. Nature 2004 , 430:317-322

7. Ma X, Sayed N, Beuve A, van den Akker F: NO and CO differentially activate soluble guanylyl cyclase via a heme pivot-bend mechanism. EMBO J 2007, 26:578-588.

8. Russwurm M, Koesling D: NO activation of guanylyl cyclase. EMBO J 2004, 23:4443-4450.

9. Cary SP, Winger JA, Derbyshire ER, Marletta MA: Nitric oxide signaling: no longer simply on or off. Trends Biochem Sci 2006, 3I:23I-239.

10. Cary SP, Winger JA, Marletta MA: Tonic and acute nitric oxide signaling through soluble guanylate cyclase is mediated by nonheme nitric oxide, ATP, and GTP. Proc Natl Acad Sci 2005 , 102:13064-13069.
Publish with BioMed Central and every scientist can read your work free of charge

"BioMed Central will be the most significant development for disseminating the results of biomedical research in our lifetime. "

Sir Paul Nurse, Cancer Research UK

Your research papers will be:

- available free of charge to the entire biomedical community

- peer reviewed and published immediately upon acceptance

- cited in PubMed and archived on PubMed Central

- yours - you keep the copyright

Submit your manuscript here:

http://www.biomedcentral.com/info/publishing_adv.asp
BioMedcentral 